\title{
GTPase-Activating Protein SH2-SH3 Domains Induce Gene Expression in a Ras-Dependent Fashion
}

\author{
RENÉ H. MEDEMA, ${ }^{1}$ WOUTER L. DE LAAT, ${ }^{1}$ GEORGE A. MARTIN, ${ }^{2}$ \\ FRANK MCCORMICK, ${ }^{2}$ AND JOHANNES L. BOS ${ }^{1 *}$ \\ Laboratory for Physiological Chemistry, University of Utrecht, Vondellaan 24A, \\ 3521 GG Utrecht, The Netherlands, ${ }^{1}$ and Department of Molecular Biology, \\ Chiron Corporation, Emeryville, California $94608^{2}$
}

Received 1 April 1992/Accepted 21 May 1992

\begin{abstract}
The p21 $^{\text {ras }}$ GTPase-activating protein (GAP) is thought to function as both a negative regulator and a downstream target of $\mathrm{p21}^{\text {ras }}$. Here, we have investigated the role of GAP by using a transient expression assay with a fos luciferase reporter plasmid. We used GAP deletion mutants that lack the domain involved in interaction with p21 $^{\text {ras }}$ and encode essentially only the SH2-SH3 domains. When these GAP deletion mutants were expressed, we observed a marked induction of fos promoter activity similar to induction by activated p21 ${ }^{\text {nas }}$. Expression of a full-length GAP construct had no efiect on the activity of the fos promoter. Activation of the fos promoter by these GAP SH2-SH3 regions was inhibited by cotransfection of a dominant inhibitory mutant of p21 ${ }^{\text {ras }}$, Ras(Asn-17). Thus, the induction of gene expression by GAP SH2-SH3 domains is dependent on p21 $^{\text {ras }}$ activity. Moreover, induction of fos promoter activity by GAP SH2-SH3 domains is increased severalfold after cotransfection of an activated mutant of p21 ras, Ras(Leu-61), or insulin stimulation of A14 cells, both leading to an increase in the levels of GTP-bound p21 ${ }^{\text {ras }}$. The combined efiect of $\operatorname{Ras}($ Leu-61) and the GAP deletion mutants was not inhibited by Ras(Asn-17), indicating that GAP SH2-SH3 domains do not function to activate endogenous p21 $^{\text {ras }}$ but cooperate with another signal coming from active p21 ${ }^{\text {ras }}$. These data suggest that GAP SH2-SH3 domains serve to induce gene expression by $\mathbf{p 2}^{\text {ras }}$ but that additional signals coming from $\mathrm{p}^{\text {ras }}$ are required for them to function.
\end{abstract}

The products of the ras genes play an important role in the regulation of cellular growth and differentiation. Their potential to induce transformation and their role in signal transduction have been studied extensively $(3,5,6)$. So far, it seems well established that $\mathrm{p} 21^{\text {ras }}$ proteins are involved in signaling from a number of receptors of the tyrosine kinase family (16). This notion is supported by the fact that mitogenicity induced by a number of growth factors can be blocked by a neutralizing anti-Ras antibody (27) and by the action of a dominant inhibitory mutant of p21 ras (9). Also, activation of $\mathrm{p} 21^{\text {ras }}$ by a shift to the GTP-bound form has been reported to take place upon activation of a number of tyrosine kinase receptors $(8,11,14,30,31)$. The mechanism by which this activation takes place is still unknown. However, a possible link between p $21^{\text {ras }}$ and tyrosine kinase signaling is provided by the $21^{\text {ras }}$ GTPase-activating protein (GAP).

GAP can negatively regulate $\mathrm{p} 21^{\text {ras }}$ activity by increased hydrolysis of GTP bound to p21 ras $(33,36)$. The COOHterminal domain of GAP is responsible for this catalytic effect on p21 ras GTPase activity (20). In addition, through its src-homology domains (SH2-SH3), GAP can associate with tyrosine-phosphorylated proteins $(2,25)$ such as the plateletderived growth factor receptor (18), epidermal growth factor receptor (19), the insulin receptor (28), v-src $(7,29)$, and two proteins of 190 and $62 \mathrm{kDa}(12)$. Also, GAP is phosphorylated on tyrosine in cells that are stimulated by platelet-derived growth factor (24), epidermal growth factor (12), or insulin (28) and in cells expressing v-src (12). Interestingly, all of these tyrosine kinases have been re-

* Corresponding author. ported to activate p21 ras to some extent $(8,14,30,31)$, but at present, no effect of tyrosine phosphorylation on the catalytic activity of GAP on p $21^{\text {ras }}$ has been observed. Only GAP associated with the $190-\mathrm{kDa}$ protein seems to have a reduced activity (26).

Apart from negatively regulating $\mathrm{p} 21^{\text {ras }}$, GAP has been proposed to serve as a downstream target of $\mathrm{p} 21^{\text {ras }}$, since it interacts with a region of p21 ras implicated in effector function $(1,10)$. Direct proof for such a function of GAP was obtained with isolated atrial cell membranes, in which interaction between $\mathrm{p} 21^{\text {ras }}$ and GAP can inhibit the carbacholinduced opening of $\mathrm{K}^{+}$channels (38). This inhibition most likely occurs through an uncoupling of the heterotrimeric $G$ protein $\left(G_{k}\right)$ and the muscarinic receptor. The $\mathrm{SH} 2-\mathrm{SH} 3$ domains of GAP are responsible for this effect (21). These domains can inhibit the opening of potassium channels in a ras-independent manner when the region of GAP that interacts with p21 ras is deleted. From these data, a model in which GAP is enabled to interact with its target through a conformational change induced upon binding of $\mathrm{p} 21^{\text {ras }}$ was proposed (21).

Here, we have examined the role of GAP in the induction of gene expression. Activation of $\mathrm{p} 21^{\text {ras }}$ has been shown to lead to the induction of fos promoter activity in a transient assay system (23). We tested whether transfection of fulllength GAP or GAP SH2-SH3 domains would result in the induction of gene expression. The deletion mutants encoding GAP SH2-SH3 domains strongly induce of fos promoter activity when transiently expressed, whereas full-length GAP has no effect. In addition, the effect of GAP SH2-SH3 domains is dependent on the activity of $\mathrm{p} 21^{\text {ras }}$ and cooperates with increased levels of active p $21^{\text {ras }}$. 


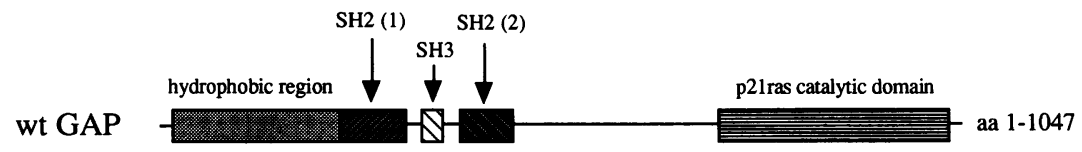

GAP32

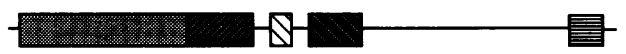

$\Delta$ aa $724-1047$

$\Delta$ aa $1-180$

$\Delta$ aa $447-1047$

FIG. 1. Structure of GAP expression plasmids. The wild-type GAP clone (wt GAP) contains the full-length human type 1 GAP cDNA from clone 101 (34). At the NH2 terminus, it has a hydrophobic stretch of about 180 amino acids and the src-homology regions, SH2 (1), SH3, and $\mathrm{SH} 2$ (2), adjacent to it. The region important for the activation of $\mathrm{p} 21^{\text {ras }}$ GTPase activity is located at the COOH-terminal part of the protein (amino acids 714 to 1047). The GAP32 deletion mutant lacks amino acids 724 to 1047, a major part of the catalytic domain. GAP37 lacks amino acids 1 to 180, the hydrophobic stretch, and amino acids 447 to 1047, which are all amino acids COOH terminal to SH2 (2), and encodes almost only the SH2-SH3 regions.

\section{MATERIALS AND METHODS}

Cell culture and transfection. Cells were cultured in Dulbecco's modified Eagle medium (GIBCO) supplemented with $10 \%$ fetal calf serum (GIBCO) and $0.05 \%$ L-glutamine. A14 cells are NIH 3T3-derived cell lines, expressing approximately $3 \times 10^{5}$ insulin receptors per cell, that have been described previously (8). Transient transfections in A14 cells were carried out by using the DEAE-dextran method (15). Chinese hamster ovary cells (CHO9) were transfected by using the calcium phosphate method (35) in combination with a glycerol shock as described previously (23). After being transfected, cells were cultured for $48 \mathrm{~h}$ in Dulbecco's modified Eagle medium supplemented with $0.5 \%$ fetal calf serum. Where indicated, cells were stimulated with insulin $(10 \mu \mathrm{g} / \mathrm{ml}) 24 \mathrm{~h}$ prior to harvesting. Cells were lysed at room temperature in a buffer containing $15 \%$ glycerol, $1 \%$ Triton $\mathrm{X}-100,0.1 \mathrm{M}$ potassium phosphate buffer ( $\mathrm{pH} 7.8), 1 \mathrm{mM}$ dithiothreitol, and $8 \mathrm{mM} \mathrm{MgCl} 2$ for $10 \mathrm{~min}$ and collected by scraping with a rubber policeman. Lysates were cleared by centrifugation in an Eppendorf centrifuge for $10 \mathrm{~min}$. Luciferase activity was determined as described before (23).

Recombinant plasmids. The fos luciferase construct and Rous sarcoma virus (RSV)-driven constructs, RSV.neo, RSV.Ras(Asn-17), and RSV.Ras(Leu-61), were described previously (23). The full-length wild-type GAP expression vector was constructed by insertion of the cDNA from pUC101 (34), containing the complete human cDNA of GAP, into pRSV.H20 (23). The construction of cDNAs encoding GAP37 and GAP32R was described previously (21). For transient expression, these cDNAs were cloned into the pcDNA I vector (Invitrogen) under control of the cytomegalovirus promoter and enhancer.

\section{RESULTS}

Induction of c-fos expression by GAP deletion mutants. Two different GAP deletion mutants were constructed from a full-length human GAP cDNA. The structure of each of the GAP constructs is shown in Fig. 1. The wild-type GAP cDNA contains the complete coding sequence of human type $1 \mathrm{GAP}$. It contains a hydrophobic $\mathrm{NH} 2$ terminus of about 180 amino acids, the src-homology regions (SH2-SH3) directly adjacent to it, and the catalytic domain responsible for activation of the p21 ras GTPase activity in the $\mathrm{COOH}$ terminal part of the protein (20). GAP32 lacks a substantial part of the region for $\mathrm{p} 21^{\text {ras }}$ interaction. GAP37 lacks both the hydrophobic stretch and the catalytic domain and encodes essentially only the SH2-SH3 regions. Both proteins were shown to function in a manner independent of $\mathrm{p} 21^{\text {ras }}$ in the uncoupling of the muscarinic receptor from its $G$ protein in a previous study (21). We used Chinese hamster ovary cells (CHO9) and an NIH 3T3-derived cell line expressing high levels of the human insulin receptor (A14) to test the effect of the GAP deletion mutants. Transfection of the full-length GAP construct did not affect the expression driven by the fos promoter (Fig. 2). In contrast, a severalfold induction was observed after the transfection of GAP32 and GAP37 clones in both cell lines (Fig. 2). Transfection of the GAP37 construct especially resulted in a strong induction (5to 10 -fold) of fos promoter activity.
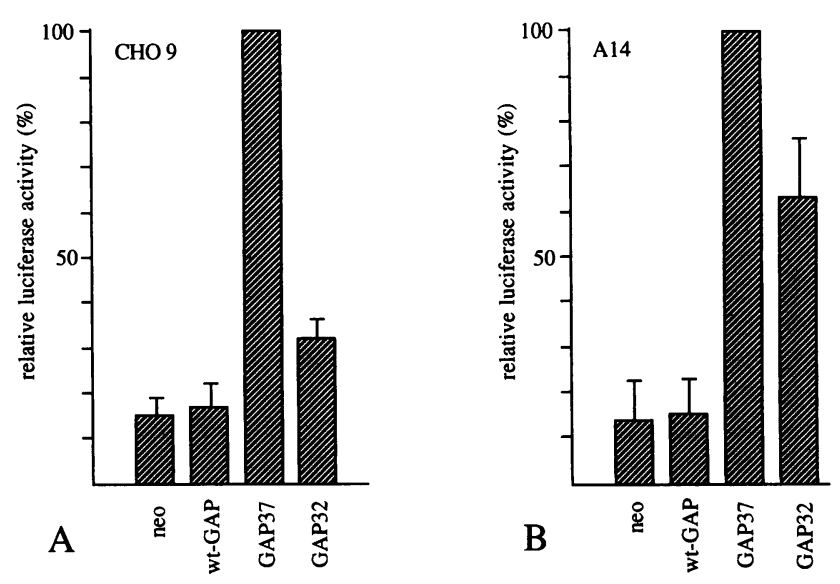

FIG. 2. Induction of gene expression by GAP SH2-SH3 domains. Cells were transfected with $4 \mu \mathrm{g}$ of fos luciferase in combination with $6 \mu \mathrm{g}$ of RSV.neo, RSV.GAP, CMV.GAP32, or CMV. GAP37 per 9-cm dish. The results for CHO9 cells transfected by calcium phosphate precipitation of DNA (A) and A14 cells transfected by DEAE-dextran-mediated DNA uptake (B) are shown. After being transfected, cells were grown on Dulbecco's modified Eagle medium supplemented with $0.5 \%$ fetal calf serum. Lysates were made $48 \mathrm{~h}$ after transfection and tested for luciferase activity. Activities are expressed relative to the activity found in cells transfected with GAP37. Error bars represent the standard deviation for each value $(n=6)$. 

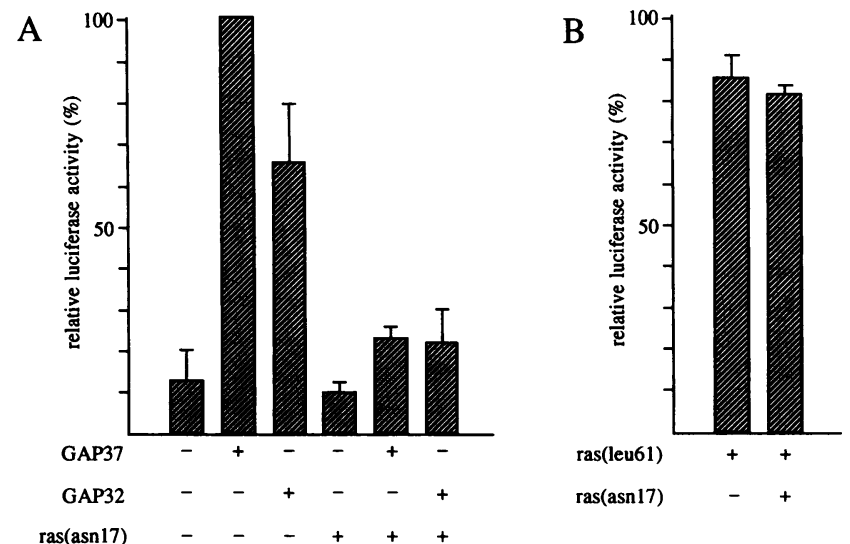

FIG. 3. Ras dependence of induction by GAP SH2-SH3 domains. A14 cells were transfected with $4 \mu \mathrm{g}$ of fos luciferase in combination with $6 \mu \mathrm{g}$ of CMV.GAP32 or CMV.GAP37 or $4 \mu \mathrm{g}$ of RSV.Ras(Asn-17) where indicated (A). As a control for the specificity of inhibition by Ras(Asn-17), A14 cells were transfected with $4 \mu \mathrm{g}$ of fos luciferase in combination with $2 \mu \mathrm{g}$ of RSV.Ras(Leu-61) [ras(leu61)] with or without $4 \mu \mathrm{g}$ of RSV.Ras(Asn-17) [ras(asn17)] (B). The total amount of DNA in all precipitates was adjusted to 14 $\mu \mathrm{g}$ with RSV.neo. After being transfected, cells were grown on Dulbecco's modified Eagle medium plus $0.5 \%$ fetal calf serum, and lysates were made after $48 \mathrm{~h}$. Luciferase activity in these lysates is expressed relative to the activity found in cells transfected with GAP37. Error bars represent the standard deviation in each value ( $n$ =4).

Ras dependence of gene induction by GAP32 and GAP37. We examined the Ras dependence of induction by GAP32 and GAP37 in A14 cells by using cotransfection with a dominant inhibitory mutant of $\mathrm{p} 21^{\text {ras }}$. This mutant, Ras(Asn17), has been shown to specifically inhibit the induction of gene expression by normal p21 ras $(23)$, most likely through competition for the exchange factor of p21 ras necessary for activation (13). Cotransfection of Ras(Asn-17) with either GAP32 or GAP37 resulted in an inhibition of fos promoter activity (Fig. 3). The residual fos promoter activity after the cotransfection of GAP SH2-SH3 domains and Ras(Asn-17) may suggest that induction of gene expression by GAP SH2-SH3 domains can also take place by a route independent of p21 ras. Also, in CHO9 cells, cotransfection of Ras(Asn-17) inhibited GAP32- and GAP37-induced activation of the fos promoter (data not shown). As a control for inhibition with $\operatorname{Ras}($ Asn-17), we transfected this construct together with an activated mutant of $\mathrm{p} 21^{\text {ras }}$, Ras(Leu-61). The induction of fos promoter activity observed with Ras(Leu-61) was not affected by Ras(Asn-17) (Fig. 3), demonstrating that $\operatorname{Ras}($ Asn-17) specifically inhibits activation of normal p21 ras.

Cooperation between GAP37 and activated p21 ${ }^{\text {ras }}$. The Ras dependence of gene induction by GAP32 and GAP37 suggests that the $\mathrm{SH} 2-\mathrm{SH} 3$ regions function upstream of $\mathrm{p} 21^{\text {ras }}$, since inhibition at the level of $\mathrm{p} 21^{\text {ras }}$ blocks their activity. However, another possible explanation for these findings could be that $\mathrm{SH} 2-\mathrm{SH} 3$ domains require another signal from p21 ${ }^{\text {ras }}$ in order to function. We therefore examined whether an increase in the level of active p21 ras would lead to an increased activation of the fos promoter by the $\mathrm{SH} 2-\mathrm{SH} 3$ regions. In fibroblasts that overexpress the insulin receptor, like the A14 cells (approximately $3 \times 10^{5}$ receptors per cell), insulin stimulation leads to a rapid activation of $\mathrm{p}^{2} 1^{\text {ras }}$ (8). As a consequence, the luciferase expression is induced about

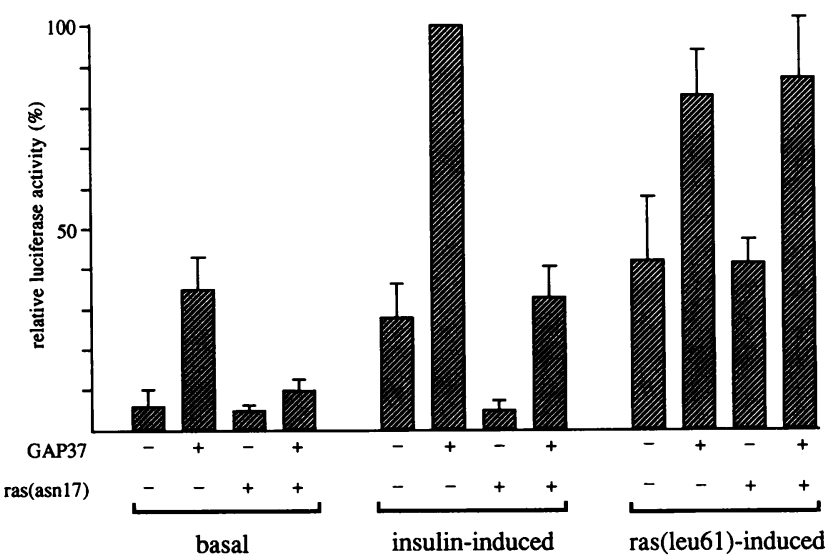

FIG. 4. Cooperation between active $\mathrm{p} 21^{\text {ras }}$ and GAP37. A14 cells were transfected with $4 \mu \mathrm{g}$ of fos luciferase in combination with $6 \mu \mathrm{g}$ of CMV.GAP37 (GAP37) in the presence or absence of $4 \mu \mathrm{g}$ of RSV.Ras(Asn-17) [ras(asn17)] where indicated. Cells were left untreated (basal) or treated with insulin $24 \mathrm{~h}$ after transfection (insulininduced), or $2 \mu \mathrm{g}$ of $\operatorname{Ras}(\mathrm{Leu}-61)$ was cotransfected [ras(leu61)induced]. The amount of DNA in each precipitate was normalized to $16 \mu \mathrm{g}$ with RSV.neo. Lysates were made $48 \mathrm{~h}$ after transfection, and luciferase activity was determined. Luciferase activity is expressed relative to the activity observed in cells transfected with GAP37 and stimulated with insulin. Error bars represent the standard deviation for each value $(n=3)$.

sixfold in A14 cells after insulin treatment (Fig. 4), similar to the level obtained with GAP32 or GAP37 alone. When GAP37 and insulin were combined, we observed a marked increase in insulin-induced luciferase activity (Fig. 4), suggesting a cooperation between active p21 ras and GAP37 in the induction of gene expression. However, this combined effect could be caused by a synergism between insulin and GAP SH2-SH3 domains at a different level. In order to exclude this possibility, we cotransfected GAP37 with an activated mutant of p $^{\text {ras }}$, Ras(Leu-61). Transfection of Ras(Leu-61) with fos luciferase also gave rise to an induction of luciferase activity, and cotransfection of GAP37 resulted in an even stronger induction (Fig. 4), which shows that GAP37 actually cooperates with active p21 ras. The effect of GAP37 and insulin together could be inhibited with Ras(Asn17) (Fig. 4), as was expected, since both insulin- and GAP37-induced gene expression is abolished by this mutant. The activity of Ras(Leu-61) is not affected by Ras(Asn-17) (Fig. 3 and 4); also, the combined effect of GAP37 and $\operatorname{Ras}($ Leu-61) was unaltered in the presence of $\operatorname{Ras}($ Asn-17) (Fig. 4). This excludes the possibility that the additional effect of GAP37 on Ras(Leu-61) induction is caused by the activation of normal endogenous $\mathrm{p} 21^{\text {ras }}$, since this effect would be inhibited by $\operatorname{Ras}($ Asn-17). Therefore, it is very unlikely that GAP37 functions through activation of endogenous $\mathrm{p} 21^{\text {ras }}$ to activate the fos promoter.

\section{DISCUSSION}

We examined the role of $21^{\text {ras }}$ GAP in the induction of gene expression by $\mathrm{p} 21^{\text {ras }}$. By using a transient expression assay with a fos luciferase reporter plasmid, we found that fragments of GAP that encode the $\mathrm{SH} 2-\mathrm{SH} 3$ regions but lack the catalytic domain (GAP32 and GAP37) can elevate the activity of the fos promoter to a level similar to that observed after transfection of activated p21 ${ }^{\text {ras }}$, whereas the full-length GAP construct was inactive. Assuming that the full-length 
GAP construct was expressed properly, this result suggests that the catalytic domain of GAP inhibits the GAP effector function. This would be in agreement with the results obtained by Martin et al. (21). They reported that GAP32 and GAP37 can inhibit the carbachol-induced opening of potassium channels in isolated membranes from chicken atrial cells in a p21 $1^{\text {ras }}$-independent manner, whereas full-length GAP can only do so in the presence of active p21 ras. Apparently, activated p $21^{\text {ras }}$ overcomes the inhibitory effect of the catalytic domain of GAP, probably by binding to it.

In a manner analogous to that of the model proposed by Martin et al., the activation of fos promoter activity by GAP32 and GAP37 was expected to be independent of p $21^{\text {ras }}$. However, the induction by GAP SH2-SH3 domains was found to be largely dependent on the activity of $\mathrm{p} 21^{\text {ras }}$, since we could inhibit the activation of gene expression with a dominant inhibitory mutant of $\mathrm{p} 21^{\text {ras }}, \operatorname{Ras}($ Asn-17). The Ras dependency of gene induction by GAP SH2-SH3 domains suggests that GAP SH2-SH3 domains can cause the activation of normal endogenous p21 ras, resulting in the induction of fos promoter activity. This would imply that the mechanism by which GAP SH2-SH3 domains activate the fos promoter is different from the mechanism by which GAP SH2-SH3 domains inhibit the carbachol-induced opening of potassium channels. An alternative explanation is that GAP SH2-SH3 domains trigger a p21 ${ }^{\text {ras }}$-independent pathway similar to that observed for the inhibition of the opening of potassium channels, but that they need an additional signal from $\mathrm{p} 21^{\text {ras }}$ to activate the fos promoter. To discriminate between these two possibilities, we have introduced active p $21^{\text {ras }}$ into this system by two methods, i.e., stimulation with insulin in A14 cells or transfection with activated p21 ras, Ras(Leu-61). If GAP SH2-SH3 domains cause an activation of normal endogenous p21 $1^{\text {ras }}$, it is expected that high levels of introduced active p21 ras would overrule the GAP32 and GAP37 effect. We observed a marked increase in fos promoter activity after the transfection of GAP37 in A14 cells treated with insulin. Also, GAP37 cooperated with Ras(Leu61 ) in the activation of the fos promoter. The possibility that this additive effect is due to an extra increment in GTPbound p21 ras induced by GAP37 is unlikely, since insulin (which activates endogenous p21 ras ) does not enhance the effect of Ras(Leu-61) on fos promoter activity in A14 cells (data not shown). Moreover, the fact that the additional effect of GAP37 on Ras(Leu-61)-induced gene expression is insensitive to Ras(Asn-17) excludes the possibility that GAP SH2-SH3 domains function through the activation of endogenous $\mathrm{p} 21^{\text {ras }}$. Therefore, our results strongly suggest that the GAP SH2-SH3 domains function separately from $\mathrm{p} 21^{\text {ras }}$ to induce fos promoter activity but require an additional signal coming from $\mathrm{p} 21^{\text {ras }}$.

The cooperation of a GAP SH2-SH3-induced signal with a signal coming from $\mathrm{p} 21^{\text {ras }}$ implies that in unstimulated A14 cells, sufficient p21 ras is in the GTP-bound state for downstream signaling, since GAP37 alone is able to activate the fos promoter. Sufficient indications are available for such a sustained effect of p21 ras to be postulated. For instance, Downward et al. (11) reported constitutive exchange activity in permeabilized $\mathrm{T}$ lymphocytes and fibroblasts, suggesting that at least a fraction of $\mathrm{p} 21^{\text {ras }}$ is complexed to GTP for a certain time. Also, in normal fibroblasts or resting $\mathrm{T}$ cells, a small but significant ( 7 to $15 \%$ ) fraction of $\mathrm{p}^{2} 1^{\text {ras }}$ is in the GTP-bound state $(8,11)$. Finally, the fact that inhibition of the opening of potassium channels by full-length GAP can be inhibited with Y13-259 indicates that active p21 ras is present in isolated membranes (38).
Our results cannot distinguish whether the GAP SH2-SH3 domains function in a pathway completely independent of p $21^{\text {ras }}$ or the GAP SH2-SH3 domains mimic the full-length GAP-p21 ${ }^{\text {ras }}$ GTP complex, as postulated in the model of Martin et al. (21). However, the fact that full-length GAP is known to interact with $\mathrm{p} 21^{\text {ras }}$ and the proposed role of GAP as the effector molecule of p21 ${ }^{\text {ras }}$ suggest that GAP SH2-SH3 domains mimic this effector molecule and function immediately downstream from $\mathrm{p} 21^{\text {ras }}$. Therefore, our current model is that $\mathrm{p} 21^{\text {ras }}$ generates two signals: one mediated by fulllength GAP, which is mimicked by the GAP SH2-SH3 domains, and one whose nature is still elusive. A candidate protein that could mediate this unknown additional signal is the product of the neurofibromatosis type 1 gene, neurofibromin, which binds to the effector domain of $21^{\text {ras }}$. Alternatively, it could be that regions of GAP other than the SH2-SH3 domains are responsible for the additional signal and that the GAP SH2-SH3 domains might not fully mimic the full-length GAP-p21 ${ }^{\text {ras }}$ GTP complex. However, Zhang and colleagues concluded from their observations on the effect of full-length GAP on transformation of cells by activated $\mathrm{p} 21^{\text {ras }}$ that it is unlikely that GAP alone is the target for $\mathrm{p} 21^{\text {ras }}$ (39).

Assuming that GAP SH2-SH3 domains play a role downstream from $\mathrm{p} 21^{\text {ras }}$, one would not expect an additional effect of GAP37 on mutant p21 ras and insulin-induced expression of the fos luciferase reporter, since activated p $21^{\text {ras }}$ would unfold endogenous full-length GAP, making the presence of additional GAP SH2-SH3 domains unnecessary. It could be that the level of endogenous GAP which can interact with activated p $21^{\text {ras }}$ is not sufficient for the full effect or that competition for binding to active $\mathrm{p} 21^{\text {ras }}$ by other proteins displaces GAP from p21 ras . In fact, neurofibromin has been shown to have an affinity for GTP-bound p21 ras 30 -fold higher than that of GAP (4). If indeed the amount of full-length GAP is limiting with respect to the induction of gene expression, one would expect that the introduction of full-length GAP would potentiate fos promoter activity under circumstances in which excess active p21 ras is available. Such an effect was observed several times in the case of Ras(Leu-61)-induced gene expression (up to fivefold extra induction [22a]). For insulin-induced gene expression, we did not observe such a cooperativity with full-length GAP. This may be due to additional negative effects of the catalytic domain of GAP on normal p21 ras (39).

In addition to GAP, a large number of proteins which contain SH2-SH3 domains have been identified, all of which interact with tyrosine-phosphorylated proteins. For instance, the crk oncogene is analogous to GAP37 in that it contains merely SH2-SH3 domains (22). This raises the question of whether the observed effects of the GAP SH2SH3 domains are specific. From the work of Kashishian et al., it is clear that the $\mathrm{SH} 2$ domains of phosphatidylinositol-3 kinase, phospholipase C-y, and GAP bind to different phosphotyrosines on the platelet-derived growth factor receptor, indicating selectivity in the binding of SH2-containing proteins (17). Furthermore, we observe only a very minor induction of fos promoter activity with the crk SH2-SH3 domains (unpublished observation). We therefore conclude that the observed effects of the GAP SH2-SH3 domains reflect specific interactions. It is attractive to speculate that the GAP SH2-SH3 domains interact specifically with a phosphotyrosine-containing protein which serves as the downstream target of the full-length GAP p21 ras -GTP complex. Candidate targets are the GAP-associated tyrosine phosphoproteins of 62 and $190 \mathrm{kDa}$. In this respect, the 
recent findings that the $62-\mathrm{kDa} \mathrm{GAP}$-associated protein might function as a heterogeneous nuclear RNA binding protein (37) and the $190-\mathrm{kDa}$ GAP-associated protein might function as a transcriptional repressor (32) are provocative.

\section{ACKNOWLEDGMENTS}

We thank Paul Polakis, Boudewijn Burgering, Bert Pronk, Lydia de Vries-Smits, Jan Paul Medema, and Loes van der Voorn for discussions and for critically reading the manuscript.

This investigation was supported in part by a grant from the Dutch Cancer Society.

\section{REFERENCES}

1. Adari, H., D. R. Lowy, B. M. Willumsen, C. J. Der, and F. McCormick. 1988. Guanosine triphosphatase activating protein (GAP) interacts with the p21 ras effector binding domain. Science 240:518-521.

2. Anderson, D., C. A. Koch, L. Grey, C. Ellis, M. F. Moran, and T. Pawson. 1990. Binding of SH2 domains of phospholipase $\mathrm{C} \gamma 1$, GAP, and src to activated growth factor receptors. Science 250:979-982.

3. Barbacid, M. 1987. ras Genes. Annu. Rev. Biochem. 56:779827.

4. Bollag, G., and F. McCormick. 1991. Differential regulation of rasGAP and neurofibromatosis gene product activities. Nature (London) 351:576-579.

5. Bourne, H. R., D. A. Sanders, and F. McCormick. 1990. The GTPase superfamily: a conserved switch for diverse cell functions. Nature (London) 348:125-132.

6. Bourne, H. R., D. A. Sanders, and F. McCormick. 1990. The GTPase superfamily: conserved structure and molecular mechanism. Nature (London) 349:117-127.

7. Brott, B. K., S. Decker, J. Shafer, J. B. Gibbs, and R. Jove. 1991. GTPase-activating protein interactions with the viral and cellular src kinases. Proc. Natl. Acad. Sci. USA 88:755759.

8. Burgering, B. M. T., R. H. Medema, J. A. Maassen, M. L. Van de Wetering, A. J. Van der Eb, F. McCormick, and J. L. Bos. 1991. Insulin stimulation of gene expression mediated by p21ras activation. EMBO J. 10:1103-1109.

9. Cai, H., J. Szeberényi, and G. M. Cooper. 1990. Effect of a dominant inhibitory Ha-ras mutation on mitotic signal transduction in NIH 3T3 cells. Mol. Cell. Biol. 10:5314-5323.

10. Cales, C., J. F. Hancock, C. J. Marshall, and A. Hall. 1988. The cytoplasmic protein GAP is implicated as the target for regulation by the ras gene product. Nature (London) 332:548551.

11. Downward, J., J. D. Graves, P. H. Warne, S. Rayter, and D. A. Cantrell. 1990. Stimulation of $\mathrm{p}^{2} 1^{\text {ras }}$ upon T-cell activation. Nature (London) 346:719-723.

12. Ellis, C., M. Moran, F. McCormick, and T. Pawson. 1990. Phosphorylation of GAP and GAP-associated proteins by transforming and mitogenic tyrosine kinases. Nature (London) 343: 377-381.

13. Feig, L. A., and G. M. Cooper. 1988. Inhibition of NIH 3T3 cell proliferation by a mutant ras protein with preferential affinity for GDP. Mol. Cell. Biol. 8:3235-3243.

14. Gibbs, J. B., M. S. Marshall, E. M. Scolnick, R. A. F. Dixon, and U. S. Vogel. 1990. Modulation of guanine nucleotides bound to ras in NIH3T3 cells by oncogenes, growth factors, and the GTPase activating protein (GAP). J. Biol. Chem. 265:2043720442.

15. Gorman, C. 1985 . High efficiency gene transfer into mammalian cells, p. 143-190. In D. M. Glover (ed.), DNA cloning: a practical approach, vol. II. IRL Press, Oxford.

16. Hall, A. 1990. The cellular functions of small GTP-binding proteins. Science 249:635-640.

17. Kashishian, A., A. Kazlauskas, and J. A. Cooper. 1992. Phosphorylation sites in the PDGF receptor with different specifici- ties for binding GAP and PI3 kinase in vivo. EMBO J. 11:13731382.

18. Kazlauskas, A., C. Ellis, T. Pawson, and J. A. Cooper. 1990. Binding of GAP to activated PDGF receptors. Science 247: 1578-1581.

19. Margolis, B., N. Li, A. Koch, M. Mohammadi, D. R. Hurwitz, A. Zilberstein, A. Ullrich, T. Pawson, and J. Schlessinger. 1990. The tyrosine phosphorylated carboxy terminus of the EGF receptor is a binding site for GAP and PLC- $\gamma$. EMBO J. 9:4375-4380.

20. Marshall, M. S., W. S. Hill, S. N. Assunta, U. S. Vogel, M. D. Schaber, E. M. Scolnick, R. A. F. Dixon, I. S. Sigal, and J. B. Gibbs. 1989. A C-terminal domain of GAP is sufficient to stimulate ras p21 GTPase activity. EMBO J. 8:1105-1110.

21. Martin, G. A., A. Yatani, R. Clark, L. Conroy, P. Polakis, A. M. Brown, and F. McCormick. 1992. GAP domains responsible for ras p21-dependent inhibition of muscarinic atrial $\mathrm{K}^{+}$channel currents. Science 255:192-194.

22. Mayer, B. J., M. Hamaguchi, and H. Hanafusa. 1988. A novel viral oncogene with structural similarity to phospholipase C. Nature (London) 332:272-275.

22a.Medema, R. H. Unpublished observations.

23. Medema, R. H., R. Wubbolts, and J. L. Bos. 1991. Two dominant inhibitory mutants of $\mathrm{p}^{\text {ras }}$ interfere with insulininduced gene expression. Mol. Cell. Biol. 11:5963-5967.

24. Molloy, C. J., D. P. Bottaro, T. P. Fleming, M. S. Marshall, J. B. Gibbs, and S. A. Aaronson. 1989. PDGF induction of tyrosine phosphorylation of GTPase activating protein. Nature (London) 342:711-714.

25. Moran, M. F., C. A. Koch, D. Anderson, C. Ellis, L. England, G. S. Martin, and T. Pawson. 1990. Src homology region 2 domains direct protein-protein interactions in signal transduction. Proc. Natl. Acad. Sci. USA 87:8622-8626.

26. Moran, M. F., P. Polakis, F. McCormick, T. Pawson, and C. Ellis. 1991. Protein-tyrosine kinases regulate the phosphorylation, protein interactions, subcellular distribution, and activity of p21 ras GTPase-activating protein. Mol. Cell. Biol. 11:1804 1812.

27. Mulcahy, L. S., M. R. Smith, and D. W. Stacey. 1985. Requirements for ras proto-oncogene function during serum-stimulated growth of NIH 3T3 cells. Nature (London) 313:241-243.

28. Pronk, G. J., R. H. Medema, B. M. T. Burgering, R. Clark, F. McCormick, and J. L. Bos. Interaction between the p21ras GTPase activating protein and the insulin receptor. Submitted for publication.

29. Pronk, G. J., P. Polakis, G. Wong, A. M. M. de Vries-Smits, J. L. Bos, and F. McCormick. 1992. Association of a tyrosine kinase activity with GAP complexes in v-src transformed fibroblasts. Oncoge \& 7:389-394.

30. Satoh, T., M. E 'o, M. Nakafuku, T. Akiyama, T. Yamamoto, and Y. Kaziro. 1990. Accumulation of $\mathrm{p} 21^{\text {ras }}$ GTP in response to stimulation with epidermal growth factor and oncogene products with tyrosine kinase activity. Proc. Natl. Acad. Sci. USA 87:7926-7929.

31. Satoh, T., M. Endo, M. Nakafuku, S. Nakamura, and Y. Kaziro. 1990. Platelet-derived growth factor stimulates formation of active p21 ras -GTP complex in Swiss mouse 3T3 cells. Proc. Natl. Acad. Sci. USA 87:5993-5997.

32. Settleman, J., V. Narasimhan, L. C. Foster, and R. A. Weinberg. 1992. Molecular cloning of cDNAs encoding the GAP-associated protein p190: implications for a signaling pathway from ras to the nucleus. Cell 69:539-549.

33. Trahey, M., and F. McCormick. 1987. A cytoplasmic protein stimulates normal $\mathrm{N}$-ras p21 GTPase, but does not affect oncogenic mutants. Science 238:542-545.

34. Trahey, M., G. Wong, R. Halenbeck, B. Rubinfeld, G. A. Martin, M. Ladner, C. M. Long, W. J. Crosier, K. Watt, K. Koths, and F. McCormick. 1988. Molecular cloning of two types of GAP complementary DNA from human placenta. Science 242:1697-1700.

35. Van der Eb, A. J., and F. L. Graham. 1980. Assay of transforming activity of tumorvirus DNA. Methods Enzymol. 65:826-839.

36. Vogel, U. S., R. A. F. Dixon, M. D. Schaber, R. E. Diehl, M. S. 
Marshall, E. M. Scolnick, I. S. Sigal, and J. B. Gibbs. 1988. Cloning of bovine GAP and its interaction with oncogenic ras p21. Nature (London) 335:90-93.

37. Wong, G., O. Müller, R. Clark, L. Conroy, M. F. Moran, P. Polakis, and F. McCormick. 1992. Molecular cloning and nucleic acid binding properties of the GAP-associated tyrosine phosphoprotein p62. Cell 69:551-558.
38. Yatani, A., K. Okabe, P. Polakis, R. Halenbeck, F. McCormick, and A. M. Brown. 1990. Ras p21 and GAP inhibit coupling of muscarinic receptors to atrial $\mathrm{K}^{+}$channels. Cell 61:769-776.

39. Zhang, K., J. E. DeClue, W. C. Vass, A. G. Papageorge, F. McCormick, and D. R. Lowy. 1990. Suppression of c-ras transformation by GTPase-activating protein. Nature (London) 346: 754-756. 